\title{
Literature Review : Hubungan Pengetahuan dan Kepatuhan Mengkonsumsi Tablet Tambah Darah dengan Kejadian Anemia Defisiensi Besi
}

\section{Literature Review : Correlation Of Knowledge and Compliance of Iron Folic Acid Supplement Consumption with Iron Deficiency Anemia}

\author{
Destania Kinthan Larasati ${ }^{1 *}$, Trias Mahmudiono ${ }^{1}$, Dominikus Raditya Atmaka ${ }^{1}$
}

\begin{abstract}
ABSTRAK
Latar Belakang: Prevalensi remaja putri yang mengalami anemia defisiensi besi di Indonesia masih tinggi. Di Indonesia angka kejadian anemia pada remaja putri mencapai $21.7 \%$. Anemia pada remaja dapat mempengaruhi konsentrasi dalam belajar, rendahnya produktifitas, dan mudah terkena infeksi. Pemerintah menjalankan program pemberian tablet tambah darah untuk menanggulangi anemia defisiensi besi pada remaja,. Tablet tambah darah diberikan pada remaja putri Sekolah Menengah Pertama (SMP) dan Sekolah Menengah Atas (SMA, dilakukan satu minggu sekali. Namun, program ini dirasa kurang efektif karena kepatuhan konsumsi tablet tambah darah pada remaja putri masih rendah. Salah satu faktor yang mempengaruhi adalah rendahnya pengetahuan remaja tentang anemia. Rendahnya pengetahuan tentang anemia berhubungan erat dengan konsumsi dan kesadaran dalam mengkonsumsi tablet tambah darah

Tujuan: Untuk mendiskusikan hubungan pengetahuan dan kepatuhan konsumsi tablet tambah darah dengan kejadian anemia pada remaja putri.

Metode: Penulisan artikel ini adalah literature review dengan bersumber dari artikel yang diterbitkan dalam kurun waktu 10 tahun dan berhubungan dengan topik yang akan dibahas. Pencarian artikel melalui database Google Scholar dan Pubmed. Terdapat 25 artikel yang diperoleh, tetapi hanya 12 artikel yang dipilih untuk diulas karena sesuai dengan topik yang akan dibahas, tujuan, sasaran, dan hasil penelitian

Hasil: Dari beberapa artikel yang telah diulas menunjukkan bahwa pengetahuan remaja terkait anemia dan kepatuhan remaja dalam mengkonsumsi tablet tambah darah berhubungan dengan kejadian anemia yang dialami oleh remaja. Pengetahuan yang baik tentang anemia dan gizi akan mempengaruhi pola makan pada remaja sehingga dapat mencegah anemia. Selain itu, patuh mengkonsumsi tablet tambah darah juga akan mempengaruhi kadar hemoglobin pada remaja

Kesimpulan: Pengetahuan remaja terkait anemia dan patuh mengkonsumsi tablet tambah darah akan mempengaruhi kadar hemoglobin pada remaja.
\end{abstract}

Kata kunci: anemia, pengetahuan, kepatuhan, tablet tambah darah, remaja putri

\section{ABSTRACT}

Background: Iron deficiency anemia among Indonesian adolescent girls prevalence still high. In Indonesia prevalence of anemia in girl adolescent reaches $21.7 \%$ Anemia in adolescent impact concentration in study, low productivity, and prone to got infection. Government already runs iron folic acid supplementation program to defeat iron deficiency anemia in adolescent. Iron folic acid supplements were given to girls adolescent in Junior High School (JHS) and Senior High School (SHS) and were doing once a week. However, this program is ineffective because compliance of iron folic acid supplement consumption in girls adolescent is still lo. One of the influencing factors is the low knowledge of adolescents about anemia. Low knowledge about anemia is closely related to consumption and awareness in consuming iron folic acid supplement.

Objectives: The aim of study was to discuss relation between knowledge and compliance of micronutrient supplementation consumption with anemia prevalence in girl adolescent 
Methods: This study was literature review with article from last 10 years and correlated with the topic. Article finding were using Google Scholar and Pubmed database. There are 25 articles that linear with the topic, but only 12 articles were chosen and discussed because its correlation with the topic, aim, and target of study

Results: The results showed that adolescent knowledge related to anemia and their compliace in iron folic acid supplement consumption were related with anemia prevalence in adolescent. Good knowledge about anemia and nutrition will affect eating patterns in adolescents so that it can prevent anemia. In addition, compliance of iron folic acid supplement consumption will also affect hemoglobin levels

Conclusions: Knowledge of adolescents related to anemia and adherence to consuming blood-supplemented tablets will affect hemoglobin levels in adolescents

Keywords: Anemia, knowledge, compliance, iron folic acid supplement, girl adolescent

\author{
*Koresponden: \\ Destania.kintan.larasati-2016@fkm.unair.ac.id \\ Destania Kinthan Larasati \\ ${ }^{1}$ Departemen Gizi, Fakultas Kesehatan Masyarakat, Universitas Airlangga, Kampus C Mulyorejo, 60115, \\ Surabaya, Jawa Timur, Indonesia
}

\title{
PENDAHULUAN
}

Anemia defisiensi besi adalah anemia yang disebabkan menurunnya cadangan besi dalam tubuh sehingga kadar hemoglobin dalam darah berkurang. Kadar normal hemoglobin pada remaja putri adalah $12 \mathrm{~g} / \mathrm{dL}$ (WHO, 2011). Di Indonesia angka kejadian anemia defisiensi besi mencapai $21.7 \%$ dan pada remaja putri masih cukup tinggi yaitu mencapai $22.7 \%$ (Kemenkes RI, 2014). Jika prevalensi anemia defisiensi besi berada pada rentang 20-39.9\%, maka dapat dianggap sebagai masalah kesehatan masyarakat yang tergolong sedang (WHO, 2011).

Remaja putri merupakan kelompok yang paling rentan untuk mengalami anemia defisiensi besi, dikarenakan remaja putri mengalami menstruasi setiap bulannya serta peningkatan kebutuhan zat besi untuk menggantikan zat besi yang hilang selama menstruasi (Briawan, Adriyani and Pusporini, 2009). Pengetahuan yang kurang juga turut andil dalam masalah anemia (Listiana, 2016).

Hemoglobin yang rendah pada penderita anemia defisiensi besi dapat menyebabkan menurunnya pengikatan dan pengangkutan oksigen dari paru-paru keseluruh tubuh (Suryani, Hafiani and Junita, 2015). Dampak jangka panjang dari remaja putri yang menderita anemia defisiensi besi adalah meningkatnya kematian ibu, meningkatnya angka Bayi Berat Lahir Rendah (BBLR), dan meningkatnya kematian prenatal (Suryani, Hafiani and Junita, 2015).

Pemerintah telah mencanangkan program Pencegahan dan Penanggulangan Anemia Gizi Besi (PPAGB) pada wanita usia subur yang bertujuan untuk mengurangi prevalensi anemia defisiensi besi pada siswi Sekolah Menengah Atas (SMA) dan siswi Sekolah Menengah Pertama (SMP). Terdapat dua kegiatan pokok dalam program ini, yaitu pemberian Informasi, Edukasi, dan Konseling (KIE) seperti penyuluhan, promosi, kampanye tentang anemia dan pemberian tablet tambah darah secara rutin (Kemenkes, 2016). Dalam praktiknya, program ini belum berjalan efektif karena tingkat kepatuhan konsumsi tablet tambah darah pada remaja putri masih rendah. Kepatuhan dalam mengkonsumsi tablet tambah darah merupakan salah satu tolak ukur keberhasilan program (Taye, Abeje and Mekonen, 2015)

Pengetahuan gizi merupakan pemahaman mengenai makanan dan komponen zat gizi, sumber zat gzi, makanan yang aman dikonsumsi, dan cata yang tepat untuk mengolah bahan makanan, serta pola hidup sehat (Putri, Simanjuntak and Kusdalinah, 2017). Hasil penelitian yang dilakukan oleh Putri (2018), pengetahuan remaja putri tetang anemia masih rendah, dari 39 responden sebanyak 23 rsponden (59\%) memiliki pengetahuan yang rendah tentang anemia. Rendahnya pengetahuan gizi anemia pada remaja putri juga berdampak terhadap tingginya kejadian anemia. Pengetahuan gizi yang baik tentang anemia akan mempengaruhi kecenderungan remaja putri dalam memilih bahan makanan sumber zat besi, menghindari makanan penghambat zat besi, dan kepatuhan mengkonsumsi tablet tambah darah ((Putri, Simanjuntak and Kusdalinah, 2017). Untuk menilai pengetahuan gizi remaja putri dapat dilakukan dengan pengisian kuesioner. Pengetahuan gizi dapat tergolong baik jika remaja putri mampu menjawab $>80 \%$ pertanyaan yang diajukan, tergolong cukup jika remaja putri mampu menjawab $60-80 \%$ pertanyaan yang diajukan, dan tergolong rendah jika remaja putri mampu menjawab $<60 \%$ dari pertanyaan yang diajukan. Tujuan dari review jurnal ini adalah untuk mengetahui pengaruh pengetahuan gizi dan kepatuhan konsumsi tablet tambah darah dengan kejadian anemia pada remaja putri. 


\section{METODE}

Metode yang digunakan dalam penulisan jurnal ini adalah literature review. Pencarian artikel melalui database internet yakni google scholar dan pubmed. Artikel yang digunakan adalah artikel yang dipublikasikan dalam rentang waktu 10 tahun terakhir. Kata kunci yang digunakan dalam pencarian artikel adalah anemia, remaja putri, pengetahuan anemia, dan kepatuhan konsumsi tablet tambah darah. Berdasarkan kata kunci tersebut terdapat 25 artikel yang berhasil diperoleh sebagai sumber referensi dan 12 artikel akan dianalisis. Artikel yang dianalisis harus memenuhi kriteria inklusi yang menunjukkan hubungan pengetahuan dan kepatuhan konsumsi tablet tambah darah dengan kejadian anemia dan sasaran penelitian harus remaja putri. Sedangkan kriteria eksklusi jika metode penelitian berupa literature review, systematic review, dan metaanalysis.

\section{DISKUSI}

\section{Pengetahuan gizi}

KIE atau Komunikasi, Informasi, dan Edukasi merupakan salah satu kegiatan dalam program Pencegahan dan Penanggulangan Anemia Defisiensi Besi pada Remaja. Pemberikan KIE dilakukan untuk meningkatkan pengetahuan tentang anemia dan perubahan pola makan sehingga asupan zat besi bisa tercukupi dan remaja dapat terhindar dari anemia (Zulaekah and Widajanti, 2010)

Remaja dengan pengetahuan tentang anemia yang rendah cenderung tidak tahu penyebab, bahaya, serta pencegahan anemia saat menstruasi (Putri and Simanjuntak, 2015). Menurut Permaesih dan Herman (2005) pengetahuan tentang gizi akan mempengaruhi pola konsumsi seseorang. Pengetahuan tentang anemia dan gizi yang rendah pada remaja akan menyebabkan pemilihan konsumsi pada remaja menyimpang. Sehingga asupan zat gizi yang masuk tidak akan mencukupi kebutuhan khususnya kebutuhan zat besi. Penelitian yang dilakukan oleh Nivedita dan Shanthini, menyebutkan pengetahuan pada wanita usia subur tentang makanan sumber zat besi masih kurang, sehingga sebanyak $81.96 \%$ wanita tidak mengkonsumsi makanan kaya sumber zat besi.

Meningkatkan asupan zat besi merupakan pilihan pertama untuk mencegah anemia. Asupan harian zat besi untuk remaja putri adalah $15 \mathrm{mg} / \mathrm{hari}$ (Kemenkes RI, 2019). Asupan zat besi dapat diperoleh dari lauk hewani seperti ikan, ayam, daging, telur dan hati, serta dari lauk nabati seperti daun bayam, kacang-kacangan, daun papaya, dan daun singkong. Selain itu, perlu diperhatikan untuk menghindari atau mengurangi konsumsi minuman yang dapat menghambat penyerapan zat besi, seperti teh dan kopi (Almatsier, 2009).

Penelitian yang dilakukan oleh Zulaekah and Widajanti (2010), Setelah melakukan KIE (Komunikasi, Informasi, Edukasi) tentang anemia dan gizi pada remaja terjadi peningkatan hemoglobin rata-rata $4.48 \mathrm{~g} / \mathrm{dL}$. Pemberian pengetahuan gizi dipadukan dengan tablet tambah darah lebih efektif meningkatkan kadar hemoglobin pada remaja, dibandingkan dengan pemberian pengetahuan gizi saja atau pemberian tablet tambah darah saja (Zulaekah and Widajanti, 2010). Menurut penelitian yang dilakukan oleh Dwiriani et al, (2011) pengetahuan remaja putri terkait anemia meningkat setelah dilakukan pendidikan gizi oleh guru bimbingan dan konseling (BK) di sekolah. Selain itu, cara efektif meningkatkan pengetahuan gizi tentang anemia kepada remaja putri adalah dengan melakukan penyuluhan disertai media buku saku (Zefaya and Nugraheni, 2017).

\section{Kepatuhan Konsumsi Tablet Tambah Darah}

Suplementasi tablet tambah darah pada remaja merupakan salah satu cara pemerintah untuk mengurangi angka kejadian anemia. Suplementasi tablet tambah darah dengan dosis yang tepat efektif untuk meningkatkan cadangan zat besi jika dikonsumsi secara rutin. Dalam penelitian yang dilakukan oleh Rahmadi (2019) sekolah yang melakukan program suplementasi tablet tambah darah memiliki prevalensi anemia yang rendah (24\%) dibandingkan dengan sekolah yang tidak melakukan program suplementasi tablet tambah darah dengan prevalensi anemia (43.1\%). Namun program suplementasi tablet tambah darah dinilai kurang efektif, karena masih banyak remaja putri yang kurang patuh mengkonsumsi tablet tambah darah. Pelaksanaan program pemberian tablet tambah darah dilakukan dengan memberikan tablet tambah darah dengan dosis 1 tablet setiap minggu nya. Remaja putri dapat dikatakan patuh mengkonsumsi tablet tambah darah jika mengkonsumsi 1 tablet setiap minggunya atau 4 tablet dalam satu bulan (Widiastuti and Rusmini, 2019).

Kepatuhan adalah perubahan perilaku seseorang dari tidak taat menjadi taat terhadap peraturan (Putri and Simanjuntak, 2015). Menurut Lacerte et al., (2011), terdapat tiga faktor yang dapat mempengaruhi kepatuhan, yaitu presdiposing factors, enabling factors, dan reinforcing factors

Presdiposing factors antara lain umur, pendidikan, pendapatan, dan pengetahuan terkait anemia dan pencegahannya. Penelitian yang dilakukan di dua provinsi di Cambodia, usia dan pendapatan tidak mempengaruhi kepatuhan dalam mengkonsumsi TTD, sedangkan pendidikan dan pengetahuan mempengaruhi kepatuhan dalam mengkonsumsi TTD (Lacerte et al., 2011). Hal tersebut juga sejalan dengan penelitian Yuniarti, Rusmilawaty and Tunggal (2015), pengetahuan remaja putri yang rendah terkait manfaat 
mengkonsumsi tablet tambah darah dan anemia yang diderita menyebabkan rendahnya kepatuhan mengkonsumsi tablet tambah darah.

Enabling factors antara lain jumlah tablet tambah darah yang diterima, penerimaan tablet tambah darah, dan efek samping. Dalam hal ini, jumlah tablet tambah darah yang diterima dapat mempengaruhi kepatuhan konsumsi (Lacerte et al., 2011). Distribusi tablet tambah darah di Indonesia masih belum maksimal, di beberapa sekolah distribusi tablet tambah darah masih belum mengikuti aturan yaitu 1 tablet dalam 1 minggu. Hal tersebut berdampak pada kepatuhan remaja putri dalam mengkonsumsi tablet tambah darah. Selain itu, efek samping yang dirasakan setelah mengkonsumsi tablet tambah darah juga dapat mempengaruhi kepatuhan, menurut penelitian Yuniarti et al, (2015) efek samping yang dirasakan oleh remaja putri antara lain mual, konstipasi, dan tinja berwarna hitam yang berujung pada ketidakpatuhan mengkonsumsi tablet tambah darah. Selain itu, remaja putri merasa tablet tambah darah tidak enak dan berbau amis.

Reinforcing factors merupakan faktor yang berasal dari lingkungan berupa dukungan dari guru, orangtua, teman, dan ketersedian tablet tambah darah (Lacerte et al., 2011)Faktor ini membuat remaja putri menjadi termotivasi untuk mengkonsumsi tablet tambah darah (Nuradhiani, Briawan and Dwiriani, 2017). Remaja putri yang mendapatkan dukungan guru 4.7 kali lebih patuh mengkonsumsi tablet tambah darah dibandingan remaja putri yang tidak mendapatkan dukungan guru. Selain itu, mengkonsumsi tablet tambah darah bersama-sama dengan teman juga dapat meningkatkan kepatuhan konsumsi tablet tambah darah dan meningkatkan kadar hemoglobin (Nuraeni et al., 2019)

Selain beberapa faktor tersebut, kendala yang dialami remaja putri dalam mengkonsumsi tablet tambah darah adalah sering merasa mual, tidak menyukai rasa dan aroma tablet tersebut, dan merasa tidak perlu untuk mengkonsumsi tablet tambah darah (Widiastuti and Rusmini, 2019). Menurut Susanti, Briawan and Martianto (2016) alasan tertinggi remaja putri tidak patuh mengkonsumsi tablet tambah darah adalah timbulnya rasa bosan dan malas

\section{KESIMPULAN}

Pengetahuan dan kepatuhan mengkonsumsi tablet tambah darah berhubungan dengan status anemia pada remaja. Pengetahuan yang baik tentang anemia dan gizi akan mempengaruhi pola makan pada remaja sehingga dapat mencegah anemia. Selain itu, patuh mengkonsumsi tablet tambah darah juga akan mempengaruhi kadar hemoglobin pada remaja. Dalam literature review ini juga dijelaskan cara efektif untuk meningkatkan pengetahuan remaja putri tentang anemia dan apa saja yang dapat mempengaruhi kepatuhan mengkonsumsi tablet tambah darah. Semoga literature review ini dapat menjadi rujukan oleh peneliti lain.

\section{ACKNOWLEDGEMENT}

Ucapan terimakasih saya sampaikan kepada Bapak Trias Mahmudiono dan Bapak Dominikus Raditya Atmaka yang telah mendukung dan membantu pembuatan literature review ini.

\section{REFERENSI}

Briawan, D., Adriyani, A. and Pusporini (2009) 'Determinan Keberhasilan Program Suplementasi Zat Besi pada Siswi Sekolah', Jurnal Gizi Klinik Indonesia, 6(2), pp. 78-83.

Dwiriani, C. M. et al. (2011) 'PENGARUH PEMBERIAN ZAT MULTI GIZI MIKRO DAN PENDIDIKAN GIZI TERHADAP PENGETAHUAN GIZI , PEMENUHAN ZAT GIZI DAN STATUS BESI', Jurnal Gizi dan Pangan, 6(3), pp. 171-177. doi: 10.25182/jgp.2011.6.3.171-177.

Jalambo, M. et al. (2018) 'Effects of iron supplementation and nutrition education on haemo- globin , ferritin and oxidative stress in iron-deficient female adoles- cents in Palestine : randomized control trial', 24(6).

Jalambo, M. O. et al. (2017) 'Improvement in Knowledge , Attitude and Practice of Iron Deficiency Anaemia among Iron-Deficient Female Adolescents after Nutritional Educational Intervention', 9(7), pp. 15-23. doi: $10.5539 /$ gjhs.v9n7p15.

Kemenkes RI (2014) Profil Kesehatan Indonesia. Kementrian Kesehatan Indonesia., Pusdatin.Kemenkes.Go.Id.

Lacerte, P. et al. (2011) 'Determinants of Adherence to Iron / Folate Supplementation During Pregnancy in Two Provinces in Cambodia', Asia-Pacific Journal of Public Health, 23(3), pp. 315-323. doi: $10.1177 / 1010539511403133$.

Listiana, A. (2016) 'Analisis Faktor-Faktor yang Berhubungan Dengan Kejadian Anemia Gizi Besi pada Remaja Putri di SMKN 1 Terbanggi Besar Lampung Tengah', Jurnal Kesehatan, 7(3), p. 455. doi: 10.26630/jk.v7i3.230.

Nuradhiani, A., Briawan, D. and Dwiriani, C. M. (2017) 'Dukungan guru meningkatkan kepatuhan konsumsi tablet tambah darah pada remaja putri di Kota Bogor', Jurnal Gizi dan Pangan, 12(3), pp. 153-160. doi: 10.25182/jgp.2017.12.3.153-160. 
Nuraeni, R. et al. (2019) 'Peningkatan Kadar Hemoglobin melalui Pemeriksaan dan Pemberian Tablet Fe Terhadap Remaja yang Mengalami Anemia Melalui “ Gerakan Jumat Pintar ” putri usia 13-18 tahun dengan prevalensi $22,7 \%$. Remaja putri lebih rentan terkena anemia', 5(2), pp. 200-221.

Permaesih, D. and Herman, S. (2005) 'FAKTOR-FAKTOR YANG MEMPENGARUHI ANEMIA PADA REMAJA Dewi $\sim$ ermaesih' dan Susilowati $\sim$ e $\mathrm{r}$ m a n ' FACTORS INFLUENCING ANEMIA AMONG ADDOLESCENTS', Buletin Penelitian Kesehatan, 33(4), pp. 162-171.

Putri, K. M. (2018) 'Hubungan Pengetahuan Dengan Kejadian Anemia Pada Remaja Putri di Wilayah Kerja Puskesmas Paal Merah 1 Kota Jambi Tahun 2018', Scientia Journal Universitas Adiwangsa Jambi, 7(01), pp. 132-141.

Putri, R. D. and Simanjuntak, B. Y. (2015) 'Pengetahuan Gizi, Pola Makan, dan Kepatuhan Konsumsi Tablet Tambah Darah dengan Kejadian Anemia Remaja Putri', pp. 404-409.

Putri, R. D., Simanjuntak, B. Y. and Kusdalinah, K. (2017) 'Pengetahuan Gizi, Pola Makan, dan Kepatuhan Konsumsi Tablet Tambah Darah dengan Kejadian Anemia Remaja Putri’, Jurnal Kesehatan, 8(3), p. 404. doi: $10.26630 / \mathrm{jk} . v 8 \mathrm{i} 3.626$.

Rahmadi, A. (2019) 'Perbedaan Status Anemia Gizi Besi Remaja Putri yang Bersekolah di SMA Program dan Non-Program Suplementasi Tablet Tambah Darah', Borneo Journal of Medical Laboratory Technology, 1(1), pp. 30-34. doi: 10.33084/bjmlt.v1i1.462.

Rajkumar, D. J. et al. (2018) 'Effect of Health Education and Iron Supplementation on Haemoglobin levels in Adolescent Girls ABSTRACT':, 11(July), pp. 2761-2764. doi: 10.5958/0974-360X.2018.00510.3.

Singh, M. et al. (2019) 'Knowledge , Attitude and Practice Change about Anemia after Intensive Health Education among Adolescent School Girls of Delhi : An Intervention Study', 9(3), pp. 71-73.

Suryani, D., Hafiani, R. and Junita, R. (2015) 'Analisis Pola Makan dan Anemia Gizi Besi pada Remaja Putri Kota Bengkulu', Analisis Pola Makan dan Anemia Gizi Besi pada Remaja Putri Kota Bengkulu, 10(1), pp. 11-18.

Susanti, Y., Briawan, D. and Martianto, D. (2016) 'Suplementasi Besi Mingguan Meningkatkan Hemoglobin Sama Efektif Dengan Kombinasi Mingguan Dan Harian Pada Remaja Putri', Journal of Nutrition and Food, 11(1), pp. 27-34. doi: 10.25182/jgp.2016.11.1.\%p.

Taye, B., Abeje, G. and Mekonen, A. (2015) 'Factors Associated With Compliance Of Prenatal Iron Folate Supplementation Among Women In Mecha District Western Amhara', Pan African Medical Journal, 20(43).

WHO (2011) 'The global prevalence of anaemia in 2011', Who, pp. 1-48.

Widiastuti, A. and Rusmini (2019) 'Kepatuhan Konsumsi Tablet Tambah Darah pada Remaja Putri', Jurnal sains Kebidanan, 1(1), pp. 12-18.

Yuniarti, Rusmilawaty and Tunggal, T. (2015) 'HUBUNGAN ANTARA KEPATUHAN MINUM TABLET FE DENGAN KEJADIAN ANEMIA PADA REMAJA PUTRI DI MA DARUL IMAD KECAMATAN TATAH MAKMUR KABUPATEN BANJAR', Jurnal Publikasi Kesehatan Masyarakat Indonesia, 2(1), pp. 31-36.

Yusoff, H. et al. (2012) 'NUTRITION EDUCATION AND KNOWLEDGE , ATTITUDE AND HEMOGLOBIN STATUS OF', 43(1).

Zefaya, K. and Nugraheni, S. . (2017) 'PENGARUH PENDIDIKAN GIZI TERHADAP PENGETAHUAN GIZI DAN TINGKAT KECUKUPAN GIZI TERKAIT PENCEGAHAN ANEMIA REMAJA (Studi Pada Siswa Kelas XI SMA Teuku Umar Semarang', Jurnal Kesehatan Masyarakat (e-Journal), 5(1), pp. 272282.

Zulaekah, S. and Widajanti, L. (2010) 'Pengetahuan gizi dan kadar hemoglobin anak Sekolah Dasar penderita anemia setelah mendapatkan suplementasi Besi dan pendidikan Gizi', Jurnal Kesehatan Masyarakat Nasional, 5(1), pp. 35-41.

WHO. (2011) 'The global prevalence of anaemia in 2011', Who, pp. 1-48. Available at: https://apps.who.int?iris/hendle/10665/177094.

Kemenkes RI. (2014) Profil Kesehatan Indonesia. Kementrian Kesehatan Indonesia., Pusdatin.Kemenkes.Go.Id.

Briawan, D., Adriyani, A. and Pusporini (2009) 'Determinan Keberhasilan Program Suplementasi Zat Besi pada Siswi Sekolah', Jurnal Gizi Klinik Indonesia, 6(2), pp. 78-83.

Dwiriani, C. M. et al. (2011) 'PENGARUH PEMBERIAN ZAT MULTI GIZI MIKRO DAN PENDIDIKAN GIZI TERHADAP PENGETAHUAN GIZI , PEMENUHAN ZAT GIZI DAN STATUS BESI', Jurnal Gizi dan Pangan, 6(3), pp. 171-177. doi: 10.25182/jgp.2011.6.3.171-177.

Jalambo, M. et al. (2018) 'Effects of iron supplementation and nutrition education on haemo- globin , ferritin and oxidative stress in iron-deficient female adoles- cents in Palestine : randomized control trial', 24(6).

Jalambo, M. O. et al. (2017) 'Improvement in Knowledge , Attitude and Practice of Iron Deficiency Anaemia among Iron-Deficient Female Adolescents after Nutritional Educational Intervention', 9(7), pp. 15-23. doi: $10.5539 /$ gjhs.v9n7p15.

Kemenkes RI (2014) Profil Kesehatan Indonesia. Kementrian Kesehatan Indonesia., Pusdatin.Kemenkes.Go.Id. 
Lacerte, P. et al. (2011) 'Determinants of Adherence to Iron / Folate Supplementation During Pregnancy in Two Provinces in Cambodia', Asia-Pacific Journal of Public Health, 23(3), pp. 315-323. doi: $10.1177 / 1010539511403133$.

Listiana, A. (2016) 'Analisis Faktor-Faktor yang Berhubungan Dengan Kejadian Anemia Gizi Besi pada Remaja Putri di SMKN 1 Terbanggi Besar Lampung Tengah', Jurnal Kesehatan, 7(3), p. 455. doi: 10.26630/jk.v7i3.230.

Nuradhiani, A., Briawan, D. and Dwiriani, C. M. (2017) 'Dukungan guru meningkatkan kepatuhan konsumsi tablet tambah darah pada remaja putri di Kota Bogor', Jurnal Gizi dan Pangan, 12(3), pp. 153-160. doi: 10.25182/jgp.2017.12.3.153-160.

Nuraeni, R. et al. (2019) 'Peningkatan Kadar Hemoglobin melalui Pemeriksaan dan Pemberian Tablet Fe Terhadap Remaja yang Mengalami Anemia Melalui “ Gerakan Jumat Pintar ” putri usia 13-18 tahun dengan prevalensi 22,7 \%. Remaja putri lebih rentan terkena anemia', 5(2), pp. 200-221.

Permaesih, D. and Herman, S. (2005) 'FAKTOR-FAKTOR YANG MEMPENGARUHI ANEMIA PADA REMAJA Dewi ermaesih' dan Susilowati e r m a n 'FACTORS INFLUENCING ANEMIA AMONG ADDOLESCENTS', Buletin Penelitian Kesehatan, 33(4), pp. 162-171.

Putri, K. M. (2018) 'Hubungan Pengetahuan Dengan Kejadian Anemia Pada Remaja Putri di Wilayah Kerja Puskesmas Paal Merah 1 Kota Jambi Tahun 2018', Scientia Journal Universitas Adiwangsa Jambi, 7(01), pp. 132-141.

Putri, R. D. and Simanjuntak, B. Y. (2015) 'Pengetahuan Gizi , Pola Makan , dan Kepatuhan Konsumsi Tablet Tambah Darah dengan Kejadian Anemia Remaja Putri’, pp. 404-409.

Putri, R. D., Simanjuntak, B. Y. and Kusdalinah, K. (2017) 'Pengetahuan Gizi, Pola Makan, dan Kepatuhan Konsumsi Tablet Tambah Darah dengan Kejadian Anemia Remaja Putri’, Jurnal Kesehatan, 8(3), p. 404. doi: $10.26630 / j k . v 8 i 3.626$.

Rahmadi, A. (2019) 'Perbedaan Status Anemia Gizi Besi Remaja Putri yang Bersekolah di SMA Program dan Non-Program Suplementasi Tablet Tambah Darah', Borneo Journal of Medical Laboratory Technology, 1(1), pp. 30-34. doi: 10.33084/bjmlt.v1i1.462.

Rajkumar, D. J. et al. (2018) 'Effect of Health Education and Iron Supplementation on Haemoglobin levels in Adolescent Girls ABSTRACT ':, 11(July), pp. 2761-2764. doi: 10.5958/0974-360X.2018.00510.3.

Singh, M. et al. (2019) 'Knowledge, Attitude and Practice Change about Anemia after Intensive Health Education among Adolescent School Girls of Delhi : An Intervention Study’, 9(3), pp. 71-73.

Suryani, D., Hafiani, R. and Junita, R. (2015) 'Analisis Pola Makan dan Anemia Gizi Besi pada Remaja Putri Kota Bengkulu', Analisis Pola Makan dan Anemia Gizi Besi pada Remaja Putri Kota Bengkulu, 10(1), pp. 11-18.

Susanti, Y., Briawan, D. and Martianto, D. (2016) 'Suplementasi Besi Mingguan Meningkatkan Hemoglobin Sama Efektif Dengan Kombinasi Mingguan Dan Harian Pada Remaja Putri', Journal of Nutrition and Food, 11(1), pp. 27-34. doi: 10.25182/jgp.2016.11.1.\%p.

Taye, B., Abeje, G. and Mekonen, A. (2015) 'Factors Associated With Compliance Of Prenatal Iron Folate Supplementation Among Women In Mecha District Western Amhara', Pan African Medical Journal, 20(43).

WHO (2011) 'The global prevalence of anaemia in 2011', Who, pp. 1-48.

Widiastuti, A. and Rusmini (2019) 'Kepatuhan Konsumsi Tablet Tambah Darah pada Remaja Putri', Jurnal sains Kebidanan, 1(1), pp. 12-18.

Yuniarti, Rusmilawaty and Tunggal, T. (2015) 'HUBUNGAN ANTARA KEPATUHAN MINUM TABLET FE DENGAN KEJADIAN ANEMIA PADA REMAJA PUTRI DI MA DARUL IMAD KECAMATAN TATAH MAKMUR KABUPATEN BANJAR', Jurnal Publikasi Kesehatan Masyarakat Indonesia, 2(1), pp. 31-36.

Yusoff, H. et al. (2012) 'NUTRITION EDUCATION AND KNOWLEDGE, ATTITUDE AND HEMOGLOBIN STATUS OF', 43(1).

Zefaya, K. and Nugraheni, S. . (2017) 'PENGARUH PENDIDIKAN GIZI TERHADAP PENGETAHUAN GIZI DAN TINGKAT KECUKUPAN GIZI TERKAIT PENCEGAHAN ANEMIA REMAJA (Studi Pada Siswa Kelas XI SMA Teuku Umar Semarang', Jurnal Kesehatan Masyarakat (e-Journal), 5(1), pp. 272282.

Zulaekah, S. and Widajanti, L. (2010) 'Pengetahuan gizi dan kadar hemoglobin anak Sekolah Dasar penderita anemia setelah mendapatkan suplementasi Besi dan pendidikan Gizi', Jurnal Kesehatan Masyarakat Nasional, 5(1), pp. 35-41. 
Tabel 1. Hasil Literature Review Artikel

\begin{tabular}{llll}
\hline \multicolumn{1}{c}{ Peneliti } & \multicolumn{1}{c}{ Subyek } & \multicolumn{1}{c}{ Metode } \\
\hline Pengaruh Pemberian Zat & 761 siswi kelas 1 dan 2 & Desain: Quasi eksperimental. \\
Multi Gizi Mikro dan & pada 3 sekolah berbeda & Subjek dibagi 3 kelompok yaitu, \\
Pendidikan & Gizi & melihat ketersediaan & suplementasi multigizi mikro \\
Terhadap Pengetahuan & guru bru bimbingan & (SG), suplementasi multigizi \\
Gizi, Pemenuhan Zat & konseling dan keadaan & mikro dan pendidikan gizi \\
gizi, dan Status Besi & sosial ekonomi murid & (SGP), dan kelompok kontrol \\
Remaja Putri & yang relatif sama. & yang tidak diberikan \\
(Dwiriani et al., 2011) & & suplementasi dan pendidikan \\
& & gizi
\end{tabular}

Dukungan guru
meningkatkan kepatuhan
konsumsi tablet tambah
darah pada remaja putri
di Kota Bogor
(Nuradhiani, Briawan
and Dwiriani, 2017)

240 siswi dari 6 Desain: Quasi eksperimental. sekolah berbeda yang Subjek dibagi 3 kelompok, yaitu sudah menstruasi, diberi kartu monitoring saja bersedia ikut dalam (M), kartu monitoring dengan penelitian, dapat penambahan TTD orang tua dan mengkonsumsi TTD, guru $(\mathrm{M}+\mathrm{T})$, dan kartu dan tidak konsumsi monitoring beserta leaflet suplemen zat besi lain. infromasi tentang anemia dan tambahan TTD guru (M+TP).

\begin{tabular}{l}
\hline Effect of Health \\
Education and Iron \\
Supplementation on \\
haemoglobin Levels in \\
Adolescent rairls \\
(Rajkumar et al., 2018)
\end{tabular}

\section{(Rejkunat et al., 2018)} kelompok A diberikan suplementasi TTD saja dan kelompok B diberikan edukasi dan suplementasi TTD selama 3

102 remaja putri Desain: Kohort prospektif
Subjek dibagi 2 kelompok, bulan.

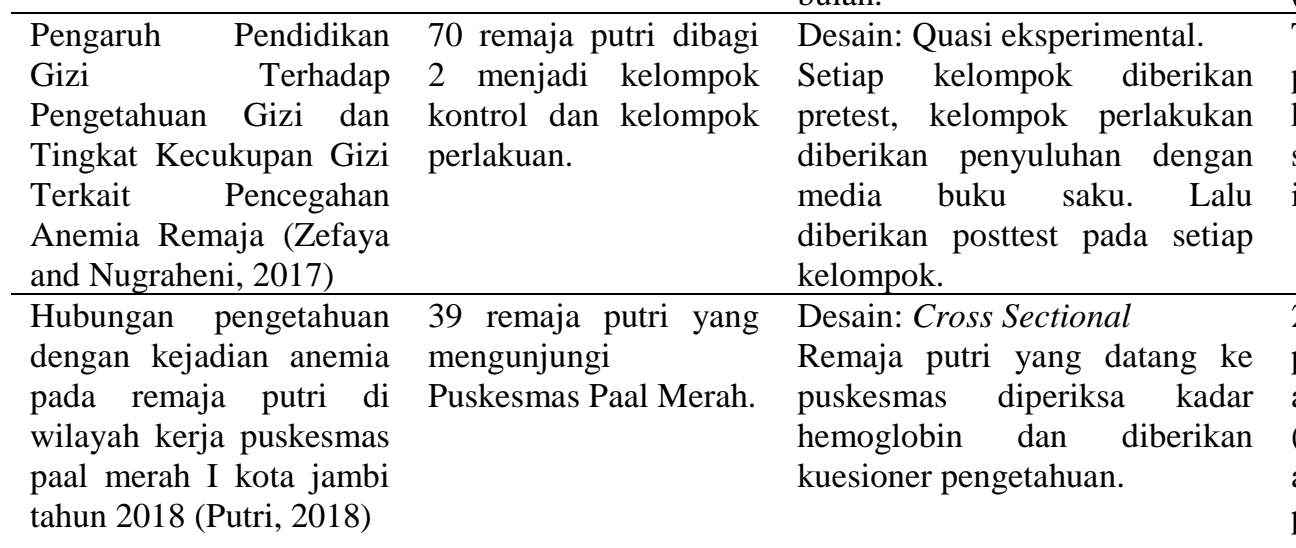

Pemberian edukasi gizi dan suplementasi lebih efektif meningkatkan kadar hemoglobin $\quad(p=0.001)$ dibandingkan dengan hanya diberikan suplementasi saja $(p=0.0068)$

Terdapat perbedaan siginifikan pengetahuan gizi $(p<0.001)$ dan kecukupan zat besi $(p=0.024)$ sebelum dan sesudah dilakukan intervensi.

23 remaja putri (59\%) memiliki pengetahuan rendah terkait anemia dan 25 remaja putri (64.5\%) terdiagnosa mengalami anemia. Terdapat hubungan pengetahuan yang rendah dengan kejadian anemia ( $p<$ 0.001). Faktor yang menyebabkan adalah remaja putri kurang memahami masalah kejadian anemia.

\begin{tabular}{|c|c|c|c|}
\hline $\begin{array}{l}\text { Pengetahuan gizi, pola } \\
\text { makan, dan kepatuhan } \\
\text { konsumsi tablet tambah } \\
\text { darah dengan kejadian } \\
\text { anemia remaja putri } \\
\text { (Putri, Simanjuntak and } \\
\text { Kusdalinah, 2017) }\end{array}$ & $\begin{array}{l}100 \text { siswi kelas } \mathrm{X} \text { dan } \\
\mathrm{XI} \quad \text { yang } \\
\text { mengkonsumsi tablet } \\
\text { Fe selama } 4 \text { minggu. }\end{array}$ & $\begin{array}{l}\text { Desain: Cross Sectional } \\
\text { Remaja putri diberikan } \\
\text { kuesioner pengetahuan untuk } \\
\text { mengukur pengetahuan gizi. } \\
\text { Data pola makan menggunakan } \\
\text { formulir FFQ. Data kepatuhan } \\
\text { dengan melihat bungkus tablet } \\
\text { dan wawancara pada remaja }\end{array}$ & $\begin{array}{l}\text { Terdapat hubungan pengetahuan } \\
\text { dengan status anemia ( } p= \\
0.018) \text {, tidak ada hubungan pola } \\
\text { makan dengan status anemia, } \\
\text { dan ada hubungan kepatuhan } \\
\text { konsumsi tablet tambah darah } \\
\text { dengan status anemia }(p= \\
0.0005) \text { Faktor yang }\end{array}$ \\
\hline
\end{tabular}




\begin{tabular}{|c|c|c|}
\hline Peneliti & Subyek & Metode \\
\hline & & $\begin{array}{l}\text { menggunakan form catatan } \\
\text { kepatuhan. }\end{array}$ \\
\hline $\begin{array}{lr}\text { Hubungan } & \text { Antara } \\
\text { Kepatuhan minum tablet } \\
\text { Fe dengan kejadian } \\
\text { anemia pada remaja putri } \\
\text { di MA Darul Imad } \\
\text { Kecamatan } & \text { Tatah } \\
\text { Makmur } & \text { Kabupaten } \\
\text { Banjar r } & \text { (Yuniarti, } \\
\text { Rusmilawaty } & \text { and } \\
\text { Tunggal, 2015) } & \\
\end{array}$ & $\begin{array}{l}49 \text { siswi kelas IX yang } \\
\text { mengalami anemia dan } \\
\text { telah diberikan tablet } \\
\text { Fe }\end{array}$ & $\begin{array}{l}\text { Desain: Cross Sectional } \\
\text { Remaja putri diberikan tablet Fe } \\
\text { selama } 6 \text { minggu dan harus } \\
\text { dikonsumsi setiap hari. }\end{array}$ \\
\hline $\begin{array}{l}\text { Study of anemia in } \\
\text { adolescents female and } \\
\text { effect information, } \\
\text { education, } \\
\text { communication (IEC) in } \\
\text { rural area of central } \\
\text { Kathmandu valley (Gupta } \\
\text { et al, 2013) }\end{array}$ & $\begin{array}{l}204 \text { siswi putri yang } \\
\text { bersekolah di } 3 \text { sekolah } \\
\text { di Jhaukhel, Bhaktapur. }\end{array}$ & $\begin{array}{l}\text { Desain: Quasi Eksperimental } \\
\text { information, education, and } \\
\text { communication (IEC) diberikan } \\
\text { selama } 3 \text { kali dalam sebulan }\end{array}$ \\
\hline $\begin{array}{l}\text { Effects of iron } \\
\text { supplementation and } \\
\text { nutrition education on } \\
\text { hemoglobin, ferritin, and } \\
\text { oxidative stress in iron- } \\
\text { deficient female } \\
\text { adolescents in Palestine: } \\
\text { randomized control trial } \\
\text { (Jalambo et al., 2018) }\end{array}$ & $\begin{array}{l}131 \text { remaja putri } \\
\text { anemia defisiensi besi }\end{array}$ & $\begin{array}{l}\text { Desain: Randomized control } \\
\text { trial } \\
\text { Subjek dibagi } 3 \text { kelompok, } \\
\text { kelompok A mendapat } 200 \mathrm{mg} \\
\text { besi fumarat selama } 3 \text { bulan, } \\
\text { kelompok } \mathrm{B} \text { mendapat } \\
\text { suplementasi besi dan sesi } \\
\text { edukasi gizi, dan kelompok C } \\
\text { tidak mendapat intervensi. }\end{array}$ \\
\hline
\end{tabular}

(Jalambo et al., 2018) tidak mendapat intervensi.

\begin{tabular}{|c|c|c|c|}
\hline $\begin{array}{l}\text { Improvement } r \text { in } \\
\text { knowledge, attitude, and } \\
\text { practice of iron } \\
\text { deficiency anaemia } \\
\text { among iron deficient } \\
\text { female adolescents after } \\
\text { nutritional educational } \\
\text { intervention (Jalambo et } \\
\text { al., 2017) }\end{array}$ & $\begin{array}{l}89 \text { remaja putri anemia } \\
\text { defisiensi besi pada } 5 \\
\text { sekolah di Jalur Gaza } \\
\text { usia } 15-19\end{array}$ & $\begin{array}{l}\text { Desain: Randomized control } \\
\text { trial } \\
\text { Subjek dibagi } 2 \text { kelompok. } \\
\text { Kedua kelompok mendapatkan } \\
\text { suplementasi zat besi } 200 \mathrm{mg} \\
\text { selama } 3 \text { bulan. Kelompok } \\
\text { perlakuan mendapatkan edukasi } \\
\text { gizi berupa presentasi, poster, } \\
\text { booklet, dan brosur. }\end{array}$ & $\begin{array}{l}\text { Pengetahuan } \\
\text { signifikan pada keningkat } \\
\text { intervensi }(\mathrm{p}<0,001) \text {. Attitude } \\
\text { dan praktik kepatuhan konsumsi } \\
\text { suplemen meningkat } \\
\text { pada kelompok interikan } \\
(\mathrm{p}<0.001 \text { dan } \mathrm{p}<0.002) .\end{array}$ \\
\hline $\begin{array}{l}\text { Knowledge, attitude, and } \\
\text { practice change about } \\
\text { anemia after intensive } \\
\text { health education among } \\
\text { adolescent school girls of } \\
\text { Delhi:an intervention } \\
\text { study (Singh et al., 2019) }\end{array}$ & $\begin{array}{l}106 \text { remaja putri kelas } \\
11 \text { sekolah menengah } \\
\text { di Delhi. }\end{array}$ & $\begin{array}{l}\text { Desain: Quasi eksperimental } \\
\text { Siswa diberikan suplementasi } \\
\text { zat besi dan asam folat setiap } \\
\text { minggu dan diberikan edukasi } \\
\text { gizi dan kesehatan intensif } \\
\text { selama } 6 \text { bulan berupa } \\
\text { presentasi, pamflet, dan gambar } \\
\text { visual makanan tinggi zat besi, } \\
\text { sayur, dan buah. }\end{array}$ & 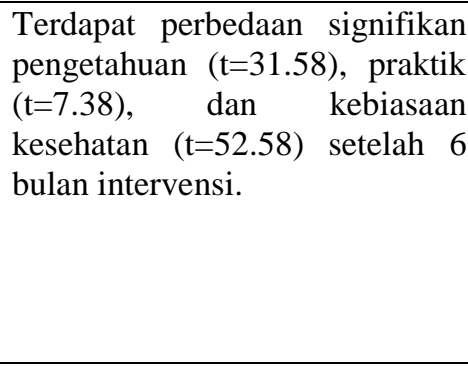 \\
\hline $\begin{array}{l}\text { Nutrition education and } \\
\text { knowledge, attitude, and } \\
\text { hemoglobin status of } \\
\text { malaysian adolescents } \\
\text { (Yusoff et al., 2012) }\end{array}$ & $\begin{array}{l}223 \text { remaja putri usia } \\
16-17 \text { tahun di } 4 \\
\text { sekolah menengah atas } \\
\text { di Tenah Merah yang } \\
\text { memiliki } \mathrm{Hb}<12 \mathrm{~g} / \mathrm{dL} .\end{array}$ & $\begin{array}{llr}\begin{array}{l}\text { Desain: } \\
\text { trial }\end{array} & \text { Randomized control } \\
\text { Subjek dibagi dalam } & 4 \\
\text { kelompok, kelompok } & 1 \\
\text { mendapat suplementasi zat besi, } \\
\text { asam folat, dan vitamin } & \text { C, }\end{array}$ & 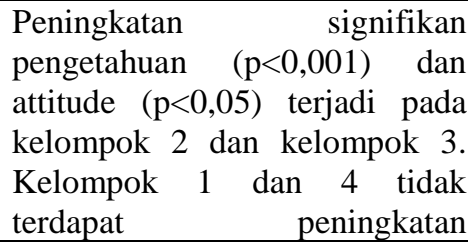 \\
\hline
\end{tabular}


